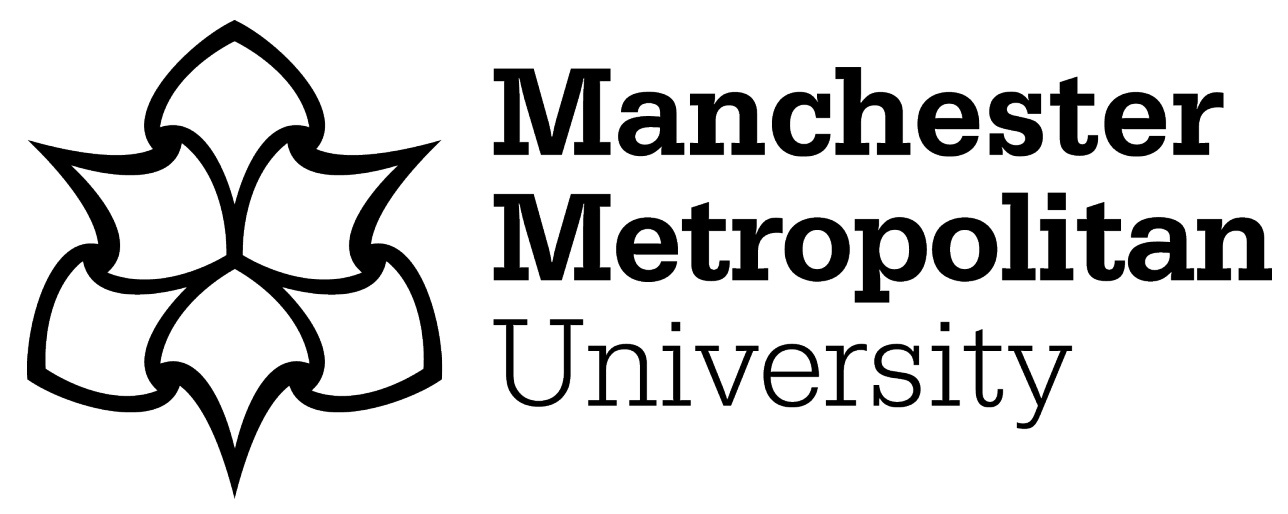

Cardoso, Daniel ORCID logoORCID: https://orcid.org/0000-0001-7864-7531 (2018) Bodies and BDSM: Redefining Sex Through Kinky Erotics. Journal of Sexual Medicine, 15 (7). pp. 931-932. ISSN 1743-6095

Downloaded from: https://e-space.mmu.ac.uk/624040/

Version: Accepted Version

Publisher: Elsevier

DOI: https://doi.org/10.1016/j.jsxm.2018.02.014

Please cite the published version 


\section{Bodies and BDSM: redefining sex through kinky erotics}

When Foucault (1994) famously separated the production of knowledge and the construction of sexuality between an oriental ars erotica and a western scientia sexualis, he intended to demonstrate the situatedness and contingency of our social categories around sexual practices, which later research showed to be not just a theoretical exercise, but a fundamental addition to reframing how the history of Europe is written (Phillips \& Reay, 2011). The same bodily acts were seen as an art form to be passed from master to disciple (e.g.: Kamasutra) in the East, but an object of study and categorization in the West (e.g.: Psycopathia Sexualis).

Michel Foucault is a famed philosopher and researcher on sexuality working from a poststructuralist perspective: he sought to deconstruct and analyze how certain categories of experience (like "sexuality") come to be used in a certain social and historical context, how their meaning changes, and the kind of relationships of power they authorize (famously, in his work, he talked about the passage from priests to medics and psychiatrists).

There is, however, another important detail. These categories of ars erotica and scientia sexualis are not only to do with sexual practice, but also with how bodies are sexed, that is, considered to be male, female, intersex, and so on - as Lynne Huffer (2009) argues, "le sexe" in Foucault does not distinguish between sex-as-practice and sex-as-physiology.

Foucault's work on this topic is a clear example of how categories that seem to describe reality are, in fact, involved in the process of creating the truth of said categories - an approach that finds even deeper resonances with Judith Butler (1999), who also explores how sex/gender and sexuality are co-constituted, entwined not only in a conceptual sense but also at the physical level. Most current societies treat bodies as having a good set of behaviors (which usually correspond to what we call heterosexuality, and especially penis-in-vagina sex), and a bad set of behaviors (usually, everything else).

Bodies are produced as male/masculine and female/feminine in a very literal sense of 'produced', as painfully exemplified by when doctors intervene surgically (and thus, technologically) on the genitalia of intersex babies without any kind of parental consent (B. Preciado, 2011). While this is usually framed as an operation of normalization, and of ensuring the supremacy of the sex-gender binary, Foucault, Preciado and Butler all talk about resistance as well, when talking about technology; about ways of redeploying this technoproductive aspect in order to reinvent and resignify bodies and lives, going so far as to advocate for print technology evolutions that would allow us to print flesh (P. B. Preciado, 2017), and thus to deeply transform the horizon of possibilities associated with our bodies.

If we consider 'technology' in a broader, more philosophical sense, in the Foucauldian sense of the term, that he employed when talking about "technologies of the self", that is to say, those things that "permit individuals to effect by their own means or with the help of others a certain number of operations on their own bodies and souls, thoughts, conduct, and way of being, so as to transform themselves" (Foucault, 1988, p. 18), then we can see how it is not only via machines that technology operates. Our own actions, and those of 
others, as long as they are aimed at a process of transformation or transcendence, can also be considered technological in nature - which is to say that they are productive, that they produce subjectivity, categories, systems of meaning and living in the world.

It is under this frame that I would like to critically think about BDSM (Bondage and Discipline, Domination and Submission, Sadism and Masochism) - as a technology, with implications that run deep both at the subjective level, and at the societal level. The connection between the subjective and societal levels is two-fold: on the one hand, everything pertaining to 'sexuality' has a level of societal influence as well as a personalized expression; on the other hand, BDSM relates to power (Mint, 2007) and thus to interpersonal modes of engagement that will often reflect historical and cultural dynamics, but it also involves a physical or psychological engagement.

Thus, a kinky erotics of sex and bodies - borrowing the expression used by Susan Sontag, who talked about "an erotics of art" (Sontag, 2001) against an hermeneutics of art - is the opening up of a field of possible ways to reinterpret what 'sex' is or means, what 'bodies' are or are for, a way for people to transform themselves and to reinvent more critical ways to conceptualize their existences, resisting the constraints of scientia sexualis.

Though this commentary might seem like little more than wordplay around how to define 'sex' - and yet, let us keep in mind that definitions are fundamental for academic work, but that they are also always impositions, and should never be taken at face value research has increasingly shown that BDSM does indeed function as a way for people to relate differently to one another and to themselves. This often has very practical clinical implications. Though space does not permit, there are myriad studies and ethnographic accounts of how kink is often used as a way to achieve some of the effects of psychotherapy, to do work around gender identity and sexual orientation, to deal with (dis)ability, and many other examples; Holmes et alii (2017) are another recent example of how empirical work framed in poststructuralist theory can advance the debates around sexualities, public health and our understanding of 'sex', 'body' and 'pleasure'.

Another poignant example of this is how some people perceive and feel distress about their own sexual problems differently when they are in a kinky context, as compared to when they are not (Pascoal, Cardoso, \& Henriques, 2015). This example does not relate to feeling that there are different sexual problems in different contexts, but rather that the distress felt about those problems is different, that they represent something different to the lived experience of those people.

It is fundamental that we continue to research sex, and people's experiences of it, but keeping an eye on what sex might be, and on how different modes of engaging with sexuality have to do with ways of relating to ourselves and others, rather than just a way of acquiring a bigger or more diverse repertoire of practices and skills. This might help clinicians and therapists encompass a perspective that opens up to potentiality and alterity, rather than closing itself down on a prescriptive notion of sex, health and pleasure.

\section{Bibliography}


Butler, J. (1999). Gender Trouble: Feminism and the Subversion of Identity. New York: Routledge.

Foucault, M. (1988). Technologies of the Self: A Seminar with Michel Foucault. (L. Martin, Ed.). University of Massachusetts Press.

Foucault, M. (1994). História da sexualidade 1: A Vontade de Saber. Lisboa: Relógio d'Água.

Holmes, D., Murray, S. J., Knack, N., Mercier, M., \& Fedoroff, J. P. (2017). Degenitalizing the sexual. BDSM practices and the deterritorialization of bodies and pleasures. In D. Holmes, S. J. Murray, \& T. Foth (Eds.), Radical Sex Between Men: Assembling Desiring-Machines (1st ed., pp. 117-141). New York: Routledge.

Huffer, L. (2009). Mad for Foucault: Rethinking the Foundations of Queer Theory. New York: Columbia University Press.

Mint, P. (2007, June 11). Towards a general theory of BDSM and power [Blog]. Retrieved December 31, 2011, from http://freaksexual.wordpress.com/2007/06/11/towards-a-general-theory-ofbdsm-and-power/

Pascoal, P. M., Cardoso, D., \& Henriques, R. (2015). Sexual Satisfaction and Distress with Sexual Functioning in a Sample of the BDSM Community: A comparison study between BDSM and Non-BDSM contexts. The Journal of Sexual Medicine, 12(4), 1052-1061. https://doi.org/10.1111/jsm.12835

Phillips, K. M., \& Reay, H. (2011). Sex before Sexuality: A Premodern History. Cambridge: Polity Press.

Preciado, B. (2011). Manifiesto contrasexual. Barcelona: Editorial Anagrama. 
Preciado, P. B. (2017, February 3). Après le livre, imprimons la chair. Libération.Fr. Retrieved from http://www.liberation.fr/debats/2017/02/03/apres-le-livreimprimons-la-chair_1546205

Sontag, S. (2001). Against interpretation, and other essays. New York, N.Y: Picador U.S.A. 